\title{
Marxisme 'n Trojaanse perd
}

HG van der Westhuizen

\section{Abstract \\ Marxism a Trojan horse}

Communism is not a direct danger at this moment in South Africa. Communism is fought against by the government. Terrorism is our daily enemy. Communism is forbidden by law. Albeit Marxism proceeds on a broad spectrum of South African life by the influence of certain academics, church leaders and politicians. The excuse is that Marxism is to be differentiated from Marxism-Leninism. The latter is supposed to be Communism. In this way Marxism eventually becomes the Trojan horse for Communism in the South African community.

\section{INLEIDEND}

Die inwoners van Troje het gereken om met die inhaal van die geweldige groot Griekse houtperd die gode se seën op Troje te konsentreer In plaas daarvan het Troje sy eie ondergang bewerk. Toe die tyd geleë is, in die nag, het die Grieke uit die houtperd gestroom en Troje se poort van binne af oopgemaak sodat die makkers kon inkom.

In hierdie stadium is Kommunisme nie 'n direkte onmiddellike gevaar vir ons volk nie. Want dit word nog bestry. Die Suid-Afrikaanse Kommunistiese Party is verbode. Die ANC is verbode. Sommige leiers van kommunistiese of kommunisties verwante inrigtings was of is in die gevangenis. Die terroristiese aanslae op ons landsgrense en binnelands word effektief en met reëlmatige sukses geneutraliseer.

Troje het vir jare, 'n volle dekade, die Griekse beleg van hulle stad weerstaan. Daarna het die Griekse leër die beleg skynbaar beëindig en hulle uit sig onttrek. Net die massiewe houtperd het agtergebly - om uiteindelik in Troje tereg te kom.

Kommunisme word nie in die openbaar in ons land bepleit en bevorder nie. Kommunistiese politiek is verbode. Maar akademiese Marxisme is nie verbode nie. Marxisme is nie teen die wet nie. Marxisme is die houtperd by die Troje van die Suid-Afrikaanse samelewing. Op die terreine van veral die sosiologie en die teologie word die Marxisme as ' $n$ bewonderenswaardige en gesogte houtperd dieper en dieper in 
Suid-Afrika ingesleep. Die Marxisme word by institute van ons universiteite bestudeer. Marxistiese handboeke word verpligtend voorgeskryf selfs vir voorgraadse studie in byvoorbeeld sosiologie by sommige van ons universiteite. Boeke oor Marxisme word teen ' $n$ toenemende tempo ook vir die Afrikaanse leser geproduseer. Die Teologie van Bevryding, die Teologie van Rewolusie en Swart Teologie is sommige van die teologiese refleksies van die Marxistiese filosofie.

Reeds in 1963 het skrywer gepleit dat ons volk geestelik gewaarsku en gewapen moet wees teen Kommunisme. Die volgende beskrywingspunt is deur die Hartswater Rapportryerskorps voor die Landsberaad van Rapportryerskorpse ingedien: 'Die Landsberaad ondersoek die moontlikheid om vertoë te rig tot die betrokke owerhede om die onderwerp "kommunisme - 'n kritiese beskouing" in te sluit by die Geskiedenisleerplanne van middelbare en hoërskole, asook as 'n studierigting by hoër-opleidingsinrigtings' (Beskrywingspunte 1963: $14 \mathrm{c}$ ). Dit was na aanleiding van 'n referaat wat later gepubliseer is, en wat soos volg eindig:

Die kommunisme is ' $\mathrm{n}$ geestelike swaard en daarom moet ons geestelik weerbaar wees. In ons volksverlede is ons al gedreig met die geestelike swaard. In die toekoms kan ons daardeur ten onder gaan, ... want kommunisme is 'n kanker. Dit moet ons so diagnoseer. En om dit te kan doen, moet ons die kanker ken - en ons kan dit alleen ken as ons Christus ken. Daarom moet kommunisme byvoorbeeld in ons skole geleer word volgens Christelike dogmatiek. Die twee bolwerke vir die behoud vir ons volk was nog altyd kerk en skool. Daarom dat in die verlede aanslae op hierdie twee gemaak is. Daarom dat ons vandag deur kerk en skool ons geestelik weerbaar moet maak (Van der Westhuizen 1965: 27).

Miskien was die vak 'Geestelike weerbaarheid' op hoërskole bedoel om iets van wat hierbo bepleit is tot sy reg te laat kom. Hoe suksesvol dit is, word nou eers daar gelaat. Die punt is: Kommunisme is vandag in ons land verbode maar Marxisme floreer!

\section{DRIE LITTE VAN EEN ORGANISME}

Kan Kommunisme en Marxisme as twee radikaal verskillende of teenoorgestelde gedagterigtings gesien word? Degenaar $(1982: 8,9)$ maak 'n duidelike onderskeid: 
Marxism is a humanistic tradition while Marxism-Leninism is a totalitarian tradition ... Marxism is distinguishable from Marxism-Leninism ... Marxism-Leninism is basically mistaken and it has to be opposed. The challenge of Marxism concerning distributive economic justice is basically sound and can only be ignored at the cost of morality.

Wat word kortweg onder Marxisme, Marxisme-Leninisme en Kommunisme dan verstaan?

\subsection{Marxisme}

Marxisme het 'n veelheid van interpretasies net soos die Christendom uit ' $n$ veelheid denominasies bestaan (Vorster 1984: 16). Basies van die Marxisme is sy humanisme wat mense as gelyke sosiale wesens sien. 'Marxism will refer mainly to the philosophy of Karl Marx based on his humanism' (Degenaar 1982: 10). 'Die konsep van die mens as 'n sosiale wese (en dit beteken vir Marx 'n ménslike wese ...) is 'n sleutelkonsep in sy denke' (Esterhuyse 1984: 113).

Voortvloeiend uit Marx se sosiale humanisme kom veral die volgende punte wat hier van belang is, na vore: gelykheid, wette, strukture, stryd, individualiteit en geloof.

Marxisme leer die gelykheid van alle mense. Daarom moet alle mense ewe wees: ewe ryk of ewe arm, ewe ontwikkeld, geleerd en beskaafd, ewe vry, ewe gevoed, geklee en behuis, ewe gesond, bruikbaar en nuttig. Sou ' $n$ mens daarop wys dat die realiteite van die lewe nou eenmaal anders is, soos die vorige president van die Transkei op 02.03.1986 op die Suid-Afrikaanse televisie gesê het dat mense verskillend is in tale, tradisies, kulture, wonings en lande, is die verweer van die Marxisme deur op 'n sondebok te wys: wette!

Wette wat deur parlemente of ander gesaginstansies gemaak word, of wette wat deur eeue tradisies of deur gebruike en gewoontes gemaak word, veroorsaak mettertyd bepaalde samelewingsverbande of strukture. Hierdie strukture bevoorreg algaande sommige mense bo ander. So ontstaan byvoorbeeld die fabrieksbase en fabriekswerkers, dit wil sê klasse. Klasse bring konflik. Indien daar nie wetlike strukture was nie, sou daar nie aggressie en konflik gewees het nie. Repressie lei noodwendig tot aggressie. Dit het Sigmund Freud al van die mens in die sielkunde gesê.

Individualiteit (Esterhuyse 1984: 113) moet verdwyn en plek maak vir 
ewewees in alle opsigte. Herverdeling van besit, beskawing, standaard en gelykskakeling van ras, grondgebied, onderwys, politiek, kerk en kultuur. Inisiatief en privaatheid moet gesosialiseer word.

Die praktyk en die geskiedenis toon natuurlik dat gelykheid en vryheid botsende begrippe is (Scholtz 1968: 31). Die gelykheid van toegang van rasse tot enige woongebied of openbare vervoer, ontneem 'n individu die vryheid om ten opsigte van die betrokke sake te kan assosieer net met sy eie ras.

Sonder om die evolusionistiese en dialekties-historiese materialisme in al hulle fasette in die Marxistiese filosofie na te gaan, kan alleen uit bogenoemde al gestel word dat die Marxisme Godloos wil wees. 'n Sosialistiese humanisme van die omvang, indringendheid en konsekwentheid van die Marxisme, stoel juis op die wortel dat daar nie 'n metafisiese dimensie van die sigbare wêreld is nie. Die sienlike kom van en uit die sienlike. Daar is nie 'n onsienlike nie. Daar is nie 'n God nie. Daar is nie waarheid in die geloof in God nie. Daarom is daar ook geen verskil te make of te handhaaf tussen gelowiges (van watter aard) en ongelowiges (van watter aard) nie. Menseregte soos deur die sosialistiese humanisme van die Marxisme uitgespel, lê klem op die gelykheid en eendersheid en eenwording van 'race, sex, age, colour and creed'.

\subsection{Marxisme-Leninisme}

Marxisme-Leninisme word voorgehou as 'n 'transformation of Marx ignoring his humanism in favour of the dictatorship of the Party' (Degenaar 1982: 10). Lenin sou dan so min of meer die vlieg in die salf wees. Wat boos in die Marxisme-Leninisme is, sou net van Lenin kom. 'He introduced the concept of the Party ... This dictatorship of the Party is illustrated by his view that an opponent should not be corrected but destroyed' (Degenaar 1982: 12).

Terwyl Marxisme positief beoordeel word, word Marxisme-Leninisme veroordeel: 'While boing challenged by Marxism we are threatened by Marxism-Leninism' (Degenaar 1982: 16). Veral ten opsigte van die volgende sake word hierdie onderskeid gehandhaaf: ideologie, klas, politiek en revolusie.

Wat ideologie betref, word Marxisme positief gesien as ' $n$ rasionalisering van die klassestryd, terwyl Marxisme-Leninisme negatief veroordeel word as die instrumentalisering van morele waardes, soos geregtigheid en bevryding. Klas verwys vir die Marxisme bloot na die 
status van 'n groep met betrekking tot sy eienaarskap al dan nie van produkte. Marxisme-Leninisme oorbeklemtoon die konsep 'klas' ten koste van ander konsepte soos ras en so meer. Politiek in die Marxistiese benadering sou dan die grondige artikulasie van die klassekonflik in sosiale, ekonomiese en politieke verhoudinge wees, terwyl dit in Marxisties-Leninistiese sin ' $n$ baie begrensde Partyhantering van die klassekonflik sou wees. Eweneens word revolusie in Marxistiese sin baie positief gesien: 'According to Marx revolution is a historical and dialectical process which takes place through conscientisation of the proletariat. It need not be violent' (Degenaar 1982: 13). Daarteenoor is revolusie vir die Marxisme-Leninisme 'n radikale bevryding deur die omverwerping van die staat.

Teen hierdie agtergrond van 'n onderskeid tussen Marxisme en Marxisme-Leninisme, word die Marxistiese benadering van ideologie (weg met blanke regering in Suid-Afrika), klas (werkers en Swartes moet polities, sosiaal en ekonomies bekragtig word), politiek (ekonomiese krag moet gelykelik verdeel word onder alle groepe en rasse en volksgroepe), en revolusie bepleit.

Ten opsigte van revolusie sou die goeie Marxistiese benadering dan neerkom op:

In a democracy the revolution can take place through the ballotbox. In so far as South Africa is a democracy this evolutionary revolution is possible. But in so far as it is undemocratic in its treatment of non-White groups the revolution will have to take a violent nature (Degenaar 1982: 25).

\subsection{Kommunisme}

Die derde lit benewens die Marxisme, en die Marxisme-Leninisme wat kortliks ter sprake moet kom, is Kommunisme. Nadat die revolusie as mikpunt van alle Marxisme en Marxisme-Leninisme bereik is, sou dan 'n ware demokrasie volg - die diktatuur van die proletariaat, werkers of gelykes.

Die tweede stadium waarna die revolusie moet lei, is kommunisme. Dit sal 'n nuwe vreedsame samelewing wees met nuwe 'vry' mense. Dit is ' $n$ samelewing sonder klasseverskil, privaat besit en dus ook konflik, uitbuiting en aggressie (Vorster 1984: 21). 


\section{POLITIEKE HERVORMINGS}

Uit die inhoud van wat tot nou toe oor Marxisme, Marxisme-Leninisme en Kommunisme gesê is, behoort dit reeds duidelik te wees, dat baie wat onder die naam van politieke hervorming vandag in Suid-Afrika plaasvind, niks minder as Marxisme is nie. Sonder om die neo-Marxistiese teologieë, soos hulle onder bykomende invloed van Schaull, Marcuse, Freud, Bloch en andere tot stand gekom het, te bespreek (Vorster 1984 en Vorster s a), sal vervolgens net aan twee steekproefmatige aspekte wat Suid-Afrika raak, aandag gegee word.

Eerstens 'n Marxistiese politieke wil en tweedens 'n Marxistiese teologiese wil.

\subsection{Marxistiese politieke wil vir Suid-Afrika}

Die Marxistiese politiek sien Suid-Afrika as 'n ongelyke gemeenskap weens eksploitasie deur Blankes wat geld, mag, geweld en geleenthede gehad het wat die Swartes dan nie sou gehad het nie. Hierdie status quo wil Blankes handhaaf deur wette en tuislande vir Swartes. Hierdie Marxistiese analise van die gemeenskap in Suid-Afrika, hou natuurlik geen rekening met volkskap, volksbewussyn, nasionalisme, vaderland, kultuur, beskawing en so meer nie. Inteendeel! Dit alles as onewehede word verwerp. Die oplossing wat aangebied word sou dan net een van twee wees:

How can this unequal society be transformed into a just society? The Marxist-Leninist chooses the inevitability of a violent revolution. The Marxist looks for radical change which excludes violence. The radical change must take place on the basic level, namely, the distribution of economic power. Political, social and economic power is concentrated in the hands of the white ruling class. A change must take place on all three levels but real change can only be based on the economic level (Degenaar 1982: 26).

Kyk ons na wat vandag op politieke gebied in Suid-Afrika op groot skaal plaasvind, staan ' $n$ mens verstom hoe Marxistiese verandering in die politieke hervorming die greep op byna alles het. Die Marxistiese beskouing van regverdige samelewing, demokrasie, gelykheid en so meer word in 'n groot mate gewoon as uitgangspunt aanvaar. Die heersende politiek is gekaap om in kameraadskap van 'ons probleme' te praat. Die goeie uitweg uit ons Marxisties gedefinieerde probleme is 
blykbaar om Marxisme-Leninisme oorbodig te maak deur so goed en so gou moontlik Marxisties te word:

A society such as ours with its political, social and economic injustices can be exploited for Marxist-Leninist aims and the best way to cope with this is to tackle injustices on all levels and not to cover up the iniquities of our society (Degenaar 1982: 27, 28).

\subsubsection{Vier politieke implikasies}

Die Marxistiese politieke oplossing het vierderlei implikasies.

\subsubsection{Demokrasie}

Wat demokrasie betref, moet daar glo 'n verbreding kom ongesiens en met opheffing van nasionalismes, volksbewussyne en volksbestaan. 'We should not isolate ourselves from Western democratic countries. There is of course a close link between undemocratic national politics and international isolation' (Degenaar 1982: 29). Verder: 'In our rejection of the non-political means of violence to solve our problems we must eradicate the existence of structural violence created by unjust laws' (Degenaar 1982: 30).

\subsubsection{Kapitalisme}

Die tweede implikasie wat Marxisme polities in Suid-Afrika glo moet tot stand bring, het te doene met kapitalisme. Waar kapitalisme as ekonomiese sisteem opgebou word uit privaatbesit, individuele inisiatief en produksiekompetisie, en geassosieer word met nasionalisme en Swart tuislande as neo-kolonialisme, word daar nog soekend rondgetas na 'n aanvaarbare kombinasie van goeie elemente uit bogenoemde faktore en Marxisme; in elk geval 'the implementation of an economic system in which a more just distribution of wealth is possible' (Degenaar 1982: 33). Die onregverdigheid van $20 \%$ (Blankes) wat $87 \%$ grond besit teenoor $80 \%$ (Swartes) wat $13 \%$ besit, moet opgehef word. By so 'n Marxistiese redenasie word baie faktore eenvoudig buite rekening gelaat soos: Watter land is wie se land? Dit is die mees basiese vraag omdat dit te doene het met volksbewussyne, kulture en so meer. Die geskiedenis bestaan tog. Onuitgesorteerde koloniale imperialistiese erfenisse is prioriteite in die roepe na oplossings van politieke pro- 
bleme. Die 'derde wêreld' kan nie geografies wat grondbesit betref, en in ander opsigte, sommer met die 'eerste wêreld' in Suid-Afrika gelykgestel word nie.

\subsubsection{Pluralisme}

'n Derde implikasie van die Marxistiese beïnvloede antwoord is pluralisme as 'n politieke model. Daarmee word Marxisme-Leninisme, nasionalisme en liberalisme verwerp. Met pluralisme word in Suid-Afrika dan bedoel die voortskryding van konflik pluralisme na konsosiatiewe pluralisme.

The unjust apartheid society created by Afrikaner nationalism and capitalism is an example of conflict pluralism. Which is dangerously explosive. The second step is taken when the leaders of the different groups negotiate, while in the third phase the groups accept one another in the sense of working together towards an open society (Degenaar 1982: 34).

'n Mens vra aan die geskiedenis waar op aarde in soortgelyke omstandighede as dié in Suid-Afrika nasionalismes vernietig is en pluralisme geslaag het? 'Pluralism should not be used as a rationalisation of apartheid with the intention of perpetuating nationalism and its apartheid policy under a new label' (Degenaar 1982: 35). Is dit humanitêr om eenvoudig ' $n$ realiteit van menswees soos volksbewussyn en alles wat daarmee regverdig saamgaan, af te kap?

\subsubsection{Godsdiens}

Die Marxistiese benutting van godsdiens vereis dat teologie en kerk sy hiernamaalsdenke moet verander om 'n sosialistiese hiernoumaalstaak te verrig. Sy hiernoumaalstaak is om nie die status quo diensbaar te wees nie, maar 'n aktivistiese rol in die politieke hantering van die sosiale probleme van onderdruktes te speel. Daarvoor 'the church can endeavour to become an "alternative community" in which class and racial barriers are broken down' (Degenaar 1982: 37). Teologiese klemverskuiwings vind inderdaad op groot skaal plaas in die ekumeniese kringe van die Wêreldraad van Kerke (Van der Westhuizen 1983).

Dit bring ons by die Marxistiese teologiese wil in Suid-Afrika. 


\subsection{Marxistiese teologiese wil vir Suid-Afrika}

\subsubsection{Middelaar}

Dit is skreiende ironie dat Karl Marx wat juis erns daarmee maak om die mens uit sy vervreemding te verlos, die enigste Verlosser, Jesus Christus, verloën.

Vir Marx is 'vervreemding vervreemding van die natuur. Antropologies uitgedruk: Dit is 'n onmenslike verhouding tot die natuur ... Eerstens is die mens vervreem van die produk van sy arbeid ... Hy word tweedens ook van sy produserende werksaamheid self vervreem ... Die derde vlak van vervreemding ... is die vervreemding tussen die arbeider en sy medemens' (Esterhuyse 1984: 77-82). Laastens is die mens ook vervreem van homself as persoon (Degenaar 1982: 11).

Die ware Middelaar tussen mens en God, en daarmee in al die menslike verhoudinge, word deur die Marxisme verwerp. Marxisme kom in der waarheid in die plek van God. 'Daarom kan Marx, terwyl hy toegee dat kommunisme met ateïsme begin, ook verklaar dat ateïsme nog lank nie kommunisme is nie' (Esterhuyse 1984: 129). Dit is inderdaad 'n uitgemaakte saak dat: 'Prinsipieel is daar geen vreedsame naasbestaan tussen die kommunisme en die Christendom nie' (Engelbrecht 1964: 24).

\subsubsection{Ateïsme}

Nogtans word gepleit dat kerk en teologie in Suid-Afrika positiewe waardering oor en deelname aan die Marxisme moet hê. 'For Marxism the "death of God" is a necessary condition for the concern for man' (Degenaar 1982: 15). Omdat die Godloosheid van die Marxisme 'n Godloosheid ten gunste van die mens is, word dit in die Marxisme selfs positief waardeer!

And indeed, the atheism of Marxism deserves our respect, for it is an atheism for the sake of man - man, not as an isolated sovereign individual, but as a communal being. For Marxism must be explored, and we must face the serious criticism that even the concept of God held by many Christians in South Africa is a hindrance for really coming to grips with our problems (Degenaar 1982: 36).

Indien God beskuldig word vir alles wat volgens sy Woord werklik verkeerd is met die mens en dit in onverantwoordelikheid fatalisties 
aan God oorgelaat word om daagliks te sorg dat die wêreld weer reg kom, is dit sekerlik 'n foutiewe Godsbegrip. 'We certainly need a concept of a God who does not control man and removes his responsibility but who liberates man in order for man to take full responsibility for all aspects of his life' (Degenaar 1982: 37). Sonder dat die mens sy verantwoordelikheid op God afskuif - watter Bybelse kerk en Bybelse teologie en ware gelowige in Christus doen dit? - weet die Christen dat sy hele lewe en die skepping, ten spyte van die mag van die bose waarin die hele wêreld lê, onder God se beskikking verkeer. Dit is nie Bybels nie om eensydig te sê 'humans are now endowed with the capacity to decide on the fundamental issues of life and death, of choosing between good and evil, to the point of destroying themselves and the entire creation' (Maimela 1985: 75).

\subsubsection{Kairos-dokument}

Die verbintenisse tussen Marxisme, die Wêreldraad van Kerke, die Suid-Afrikaanse Raad van Kerke, die verbode Christelike Instituut en so meer, is al voldoende aangetoon (Vorster s a: 16, 28 en Vorster 1984: 36-75).

As steekproef om aan te toon hoe ver die Marxisme met kerk en teologie in Suid-Afrika wil gaan, bepaal ons ons laastens by die sogenaamde Kairos-dokument (The Kairos document 1985). 'Die Kairosdokument is ongetwyfeld die mees radikale dokument wat nog die lig gesien het van die kant van kerklui in Suid-Afrika' (Du Toit 1986). Nie net omdat hierdie dokument duidelik radikaal is nie, maar ons kies hierdie dokument ook omdat 'vir die meeste waarnemers was dit al met die eerste oogopslag duidelik dat ons hier te make het met 'n dokument wat volledig binne die tradisie staan van die Bevrydingsteologie, en met name die Teologie van die Rewolusie' (Du Toit 1986). Prof Johan Heyns sê van hierdie dokument:

Dié dokument is nie een van versoening nie, maar een van konfrontasie. Dit is nie opgestel in die taal en die idioom van die kerk nie, maar van 'n politieke aksiegroep. Dié dokument toon geen eerbied vir die tipiese funksie en taak van die kerk nie, maar wil die kerk kaap vir sy eie politieke visie ten opsigte van die oplossing van die probleme van ons land (Heyns 1986).

Elders (Van der Westhuizen 1986) is die Kairos-dokument reeds as 'n revolusiedokument geïdentifiseer. Daarom neem ons hier nie die on- 
derhawige dokument eerstens self weer ter hand nie, maar aan die hand van 'n paar reaksies word enkele verdere opmerkings gemaak.

\subsubsection{Kairós}

Die Kairos-dokument verstaan kairós as 'the moment of truth'. Onder die 'oomblik van waarheid' word die oomblik van afrekening van apartheid verstaan. 'Die begrip Kairos wat ryk is aan teologiese betekenis en wat dui op die oomblik van finaliteit en beslissing in die lig van Christus se koms na die wêreld, word vervlak tot die oomblik van krisis en waarheid vir apartheid in Suid-Afrika' (Die Hervormer 1984: 4).

Kurt Henning is ' $n$ Duitse emeritus en was lid van die Belydende Kerk in die Derde Ryk. In sy indringende en Bybelsgetroue kommentaar op die Kairos-dokument (Henning 1986) sê hy:

Die Griekse woord kairós dui 'n bepaalde tydstip aan wat deur God gebruik word en waarin die gelowige die hand en die roepstem van God herken. Dit is egter volgens die Heilige Skrif nie 'the moment of truth' (bl 1 van die manifes - HG vd W), iets waaroor die mens se beslissing en die mens se 'wil en strewe' (Rom 9: 16; NAB - HG vd W) beskik en wat die strekking van die hele dokument is nie.

Henning wys dan verder op die bespreking van die begrip in die Theologisches Wörterbuch zum Neuen Testament IV, 459, 462.

Scarborough (1985) sê: "Kairos means "the moment of grace" as referred to in Luke 19: 40, when Jesus wept over Jerusalem, because of "the massacre of the people that was imminent", saying "You did not recognise your opportunity (KAIROS) when God offered it".'

Soos voorheen van die Marxisme gesê is dat dit God wil vervang, so sien ons dat hierdie dokument wil beskik oor die tyd en omstandigheid wat die Vader in sy eie mag bepaal.

\subsubsection{Bose owerheid}

Die dokument het volgens eerw dr Patrick Hartin (1985) vir homself 'n god geskep en volgens daardie god bepaal dat die owerheid en staat in Suid-Afrika boos is. Na aanleiding van 'n enkele vertaling van Psalm 103: 6 wat die dokument boonop buite verband gebruik, sê Hartin (soos vertaal): 
Die Kairos-dokument lees die Skrif met die voorveronderstelling dat geweld deur of namens die onderdruktes geregverdig is. Nadat hulle aan geweld voorkeur gegee het, laat hulle die Skrif sê wat hulle wil hê dat dit moet sê ... Net soos die verklaring die 'staatsteologie' daarvan beskuldig dat dit 'n eie god geskep het, so het hierdie dokument ook sy eie god geskep: 'n god wat nie meer vry is nie, maar wat voorgesê is dat hy aan die kant van die onderdruktes moet staan wat hulle eie manier - geweld - gebruik om hulle doel te bereik.

Die Dokument se Skrifhantering is inderdaad totaal onwetenskaplik en onbetroubaar. Veral twee gedeeltes moet in die verband van die owerheid genoem word: Romeine 13 en Openbaring 13.

Die Dokument se uitgangspunt is dat Romeine 13 se owerheid gehoorsaam kan word as dit 'n goeie owerheid is en nie soos Openbaring 13 se owerheid 'n bose owerheid is nie.

Henning (1986) wys daarop 'dat gelowiges ook voor 'n owerheid buig wat ooglopend boos en nie goed is nie, en dat die goeie optrede ("geregtigheid") van 'n staat geensins die kriterium daarvoor is of die Christen en die kerk daaraan moet "onderdanig" wees nie...' Gelowiges was die Romeinse owerheid gehoorsaam - ten spyte van sy heidense wette, massateregstellings en wrede ongeregtighede. Henning gaan verder: 'Net so geld dit vir die bloedsultan Nebukadneser (Jer 29: 7; Dan 1; 3: 30) en die Persiese koning Darius (Dan 6: 3); nêrens is hier of in Openbaring 13 sprake van weerstand nie, nog minder van revolusie. Inteendeel: Openbaring 13: 10!'

Henning wys verder op die feit dat die kerk nooit tot revolusie mag kom nie, maar in lyding moet volhard:

Lyding onder ' $n$ "onregverdige" owerheid is deur die eeue heen die deel van beide Israel en die kerk: Eksodus 1; Daniël 3: 1-18; Filippense 1: 12-14; Handelinge 16: 19-24; 1 Petrus 4: 12-16. In ons tyd ondergaan die kerk nou al vir dekades so 'n lyding in Rusland, terwyl die kerk ook in Roemenië, Etiopië, Angola, Viëtnam, Bulgarye en ander state vervolg word.

Openbaring 13 word totaal misbruik. Terwyl die hele Openbaring troos onder vervolging aan die gemeente wil bring, wil die Kairos-dokument revolusie daarmee stook! Hartin (1985) sê hiervan: 
Die opstellers van die Kairos-dokument bly in gebreke om hierdie boodskap van troos in Openbaring 13 uit te spel. Op geen manier pleit die boek Openbaring of enige ander deel van die Nuwe Testament vir geweld wanneer mense onderdruk of vervolg word nie. Inteendeel ....

Nie om 'n ongehoorsaambare bose owerheid, soos die Suid-Afrikaanse, gaan dit in Openbaring 13 nie, maar juis om ' $n$ verwerplike valse godsdiens, soos die Marxisme. Openbaring 13 is nie in apposisie by Romeine 13 nie, maar by Deuteronomium 13 wat oor vals profete en verdorwe godsdiens handel (vgl Van der Westhuizen 1986b: preek 20).

Henning sien dit inderdaad korrek dat Christene slegs dan direkte en passiewe weerstand ten opsigte van hulle geloof kan doen wanneer hulle gekonfronteer word om God te verloën:

Weerstand kom in die Heilige Skrif eers dan en slegs dan voor, waar mense en magte hulleself uitdruklik in die plek van God plaas, of waar hulle (soos in Hand. 5: 29) die verkondiging van die Naam en evangelie van Jesus Christus onderdruk (Heb. 12: 4; Hand 4: 18-20).

Hierdie standpunt word eenvoudig maar diepsinnig in Jesus se woorde van Matteus 22: 21 saamgevat: 'Gee dan aan die keiser wat aan die keiser behoort, en aan God wat aan God behoort.'

\subsubsection{Versoening}

Die Marxisme roep om ontvreemding, versoening en sosialisering. Maar versoening is in hierdie kringe slegs sosialisties moontlik en nie onvoorwaardelik nie. Alleen met diegene binne die dokument se doelwit is versoening moontlik. Die sogenaamde 'injustices' moet vernietig word. Omdat nasionalismes, volksbewussyne, reëlings en wette om volksoewereiniteite te beskerm, in Marxistiese sin die eintlike en wesenlike sonde is, moet almal wat meewerk om die strukture af te breek en politieke hervorming te bewerk so ver kom om ook 'skuldbelydenis' van hulle aandeel aan die 'sonde' te doen. Dan kan daar eers vergewing en gevolglik versoening kom!

Tereg word gese: 'Die Kairos-dokument ... bied geen gespreksbasis nie' (Die Hervormer 1986: 4). 


\subsubsection{Geregtigheid}

Geregtigheid, 'true justice, God's justice, demands a radical change of structures. This can only come from below, from the oppressed themselves ... God does not bring his justice through reforms introduced by the Pharaoh's of this world ...' (The Kairos document 1985: 11).

Enige poging van die regering - al sou dit ook hoe Marxisties in sy hervormings wees - word deur hierdie dokument verwerp. God se geregtigheid kom nie van daardie oord nie, ook van geen ander oord nie, as net van onder, van die onderdruktes af! Dit is ten opsigte hiervan dat gesê word: 'Die Kairos-dokument staan teologies volkome in lyn met die moderne teologie van bevryding en rewolusie en gebruik dan ook Marxistiese en Neo-Marxistiese begrippe in sy sosiale analise' (Diepteartikel 1986). Die volgende opmerking sluit hierby aan: 'Die sogenaamde profetiese teologie wat gepropageer word, is so na as wat kan kom aan 'n replika van die Latyns-Amerikaanse bevrydingsteologie' (Smith 1986: 5).

Indien die kerk saam met onderdruktes en sogenaamde onderdruktes geregtigheid moet bewerk deur 'n staat omver te werp, kan tereg gevra word: 'Waar sou die kerk en die teologie beland as sulke beginsels op die onderdrukte volke van Sowjet-Rusland, Etiopië of Afganistan toegepas word?' (Henning 1986).

Skerp en Skriftuurlik merk Henning (1986) oor geregtigheid op:

Geregtigheid uit Bybelse perspektief is nie maar net dieselfde as eweredig uitgebalanseerde menslike besittings en verdeling van regte nie, maar is altyd 'n uitdrukking van die mens se verhouding tot God. Meer as een keer is geregtigheid in die Bybel 'n sinoniem vir vroomheid (Matt 5: 20 ens). Die gedagte dat die geregtigheid wat deur God ingestel is en dus van bo kom, identies is aan 'n geregtigheid wat van onder kom en deur die 'volk' neergelê is, is uit 'n Christelike oogpunt onhoudbaar.

\subsubsection{Geweld}

Almal is dit min of meer eens dat die Kairos-dokument met die volgende woorde beskryf kan word: 'So the Kairos document is an open call to rebellion, revolution, violence and possibly assassination. (Or does one remove a "tyrant" by asking: "Please be so kind as to step down?")' (Scarborough 1985). 
Henning (1986) toon baie duidelik die ou en bekende waarheid aan dat die kerk volgens die Bybel nooit tot geweld geroep is nie. Die staat het volgens die Bybel 'n geweldmag, maar die onderdane het geen reg tot teengeweld of oproer nie 'selfs nie teenoor gewelddadige onregsbeoefening deur die owerhede nie: Johannes 18: 3-12; Lukas 22: 49. Die staatsgesag het volgens die Bybel die "noodreg tot geweld": Lukas 20: 20; Markus 10: 42; Romeine 13: 4.'

Nürnberger (1985) bewoord die Marxistiese mening asook dié van die Kairos-dokument oor opstand as 'teengeweld' korrek: 'Die Regering praat nie met die ANC nie, aangesien dié Suid-Afrika met geweld wil verander. Dié ANC praat nie met die Regering nie omdat dié die status quo met geweld probeer handhaaf.'

Die volgende opmerking van praktiese aard is veelseggend oor die filosofie wat agter die huidige sogenaamde 'teengeweld' skuil:

Die feit dat die huidige geweld byna uitsluitlik gemik is teen wetsgehoorsame Swartes (burgemeesters, raadslede, die polisie en sakelui), word deur die Kairos-teoloë geïgnoreer. Hulle verswyg verder die feit dat die weermag eers na ses maande van aanhoudende geweldpleging na die woongebiede gestuur is - 'n reaksie wat doelbewus uitgelok en ten volle verwag is deur die rewolusionêres (UcaNuus 1986).

\subsubsection{Apartheid}

Dit is baie duidelik dat die Kairos-dokument nie meer veel teen apartheid propageer nie. Dit gaan vir die Marxisme nie meer om hervorming, opruiming van apartheid, opheffing van sekere wette en genesing van maatskaplike siektes nie. Dit gaan om die dood van 'n prerevolusionêre staat. Daarom oorheers die Marxistiese terme van 'konflik', 'onderdrukker', 'onderdruktes'. 'The racial component is there but ... the conflict is between two irreconcilable causes or interests in which the one is just and the other is unjust' (The Kairos document 1985: 15).

UcaNuus (1986) som die Kairos-dokument in hierdie verband korrek op: 'Die Suid-Afrikaanse regering word uitgebeeld as die duiwel self, en die huidige konflik ontleed as 'n klassestryd tussen die "onderdrukker" en die "onderdruktes" ('n klassieke Marxistiese benadering).'

Die Kairos-dokument wil dan ook op 'n tipiese Marxistiese wyse die bestaande owerheidstruktuur omverwerp 'at all costs ... No compromise is possible' (The Kairos document 1985: 16). 


\subsubsection{Funksie van die kerk}

Die Kairos-dokument roep alle 'Christene' op tot deelname aan die 'struggle for liberation and for a just society. The campaigns of the people, from consumer boycotts to stayaways, need to be supported and encouraged by the church ... A Church ... will sometimes have to confront and disobey the State in order to obey God' (The Kairos document 1985: 22 en 24).

Om hierdie funksie van die kerk effektief deur die massas te laat uitvoer 'word 'n verkorte weergawe van die dokument op groot skaal in Swart tale in Swart gemeentes versprei. In sommige gevalle word die inhoud van kansels af behandel en voorgehou as die enigste alternatief vir Christene in Suid-Afrika ... Die opstellers veroordeel alle persone wat enigsins ' $n$ ander siening as hulle het' (Diepteartikel 1986).

Op die weg wat die Marxisme inslaan, is dit nie ver nie of mense met ander sienings as die Marxistiese word genoem: andersdenkendes, mense wat nie redelikes is nie. Vir die andersdenkendes wag in kommunistiese lande tronke of 'sielkundige inrigtings'!

Die Kairos-dokument gaan met sy sogenaamde 'profetiese teologie' (teenoor die verwerpte 'staatsteologie' en 'kerkteologie') teen die grein van die Bybelse profete en profesie in. Tereg wys Smith (1986: 7) soos volg daarop:

Die Ou Testamentiese profete wys wel keer op keer in vlymskerp taal op sosiale onreg ... Nooit gaan dit vir die profete om maatskappykritiek bloot ter wille van'n ander samelewingsorde of die verwesenliking van politieke ideale nie.

Kerk en teologie moet in Suid-Afrika 'n sensitiwiteit oor die gevare van Marxisme openbaar.

Daar bestaan geen twyfel nie dat die Kairos-dokument met ondubbelsinnige woorde ' $n$ manifes van revolusie in kommunistiese $\sin (p$ 6/7), in die gees van Leninistiese dogmatiek en etiek wil wees nie. Sy doel is die inskakeling van Suid-Afrika in die kommunistiese wêreldstelsel (Henning 1986: 8).

Kerkverloëning en Godslastering is noodwendige gevolge indien die Kairos-gees sy gang laat gaan word. Dit is die boodskap van 'n Duitse teoloog aan ons: 
Wanneer die Christelike kerk so 'n omkering van die sentrum van sy boodskap, 'die woord van die kruis' (1 Kor. 1: 18), nie weerstaan nie ... hou hy op om kerk van Jesus Christus te wees. En as die kerk aan die eis van hierdie dokument sou voldoen ... dan sou die kerk God laster (Henning 1986: 8).

\section{SLOT}

\subsection{Om ' $a$ ' en ' $b$ ' te sê}

Die geloof in Christus as ons enigste en ewige Verlosser, die aard van ons teologie, die funksie van ons kerk, veral as volkskerk, die bestaan van ons volk, en ons eie individualiteit en identiteit onder andere, is in ' $n$ bedreigde posisie vir hulle voortbestaan voor die aanslag van die Marxisme. Solzhenitsyn het gesê (aangehaal deur Jordaan 1986: 8):

Within the philosophical system of Marx and Lenin and at the heart of their psychology, hatred of God is the principal driving force more fundamental than all their political and economic pretensious ... To achieve its diabolical ends communism needs to control a population devoid of religious and national feeling, and this entails a destruction of faith and nationhood.

Daar word van ons verwag om Marxisme as iets goeds te aanvaar en maar net te waak teen die Marxisme-Leninisme en Kommunisme. Dit is egter duidelik dat wie ' $a$ ' sê vir die sisteem van die Marxistiese boom ook uiteindelik ' $b$ ' moet sê vir die boom se vrugte. Soos die Kairos-dokument (Kairos 1985: 6) van die 'mite van kommunisme' praat, wat in Suid-Afrika as die gogga gebruik sou word om die baba mee bang te makk, kan in der waarheid gepraat word van die mite van Marxisme (The myth of Marxism 1982). Marxisme en enige Marxistiese sosialisme is en loop onvermydelik uit op Marxisme-Leninisme en Kommunisme.

Ons sien dit onder andere prakties in Latyns-Amerika en SuidAfrika.

Wat het in Latyns-Amerika gebeur? Die bevrydingsteoloë het nie volstaan met die pleidooi vir groter dialoog met die Marxiste nie, maar het toenemend gebruik begin maak van die Marxistiese maatskappy-analise ... Feit is, by so ' $n$ aanknoping het dit nie gebly nie ... Christene en nie-Christene is saamverbind in ' $n$ nuwe revolusionêre broederskap ... (Smith 1986: 5). 
Twee individuele voorbeelde in Suid-Afrika spreek boekdele. Van dr Beyers Naudé, 'n voorheen ingeperkte, word gesê:

Met die toga van 'n kerkman oor sy skouers, sê dr Beyers Naudé die geweldpleging in Suid-Afrika is geregverdig en hy weier om dit te veroordeel. Dieselfde kerkman wat onder die vaandel van die Kommunistiese hamer en sekel en baniere van die verbode Suid-Afrikaanse Kommunistiese Party en die ANC ' $n$ begrafnis gehou het. Dieselfde kerkman wat vanjaar 'n oproep tot burgerlike ongehoorsaamheid gedoen het ... Ná Cottesloe het baie Afrikaners simpatie met dr. Naudé gehad oor sy standpunt oor apartheid en daar was aanvanklik ook begrip vir sy veldtog daarna. Nie meer nie (Beeld 1985).

Vandag is hy ondertekenaar en verspreider van die Kairos-dokument tot in die buiteland (Internos 1985: 110-114 en Diepteartikel 1986: 10).

'n Ander ondertekenaar van Kairos-dokument, dr Nico Smith van die NG Sendingkerk, sê volgens Star van 19.01.86, aangehaal en vertaal deur UcaNuus (1986): 'As Christen sou ek verkies om onder 'n Marxistiese regering te leef, eerder as om verdere lewensverlies te sien.'

Wanneer dit van dieselfde teoloë is wat die Kairos-dokument steun wat ook as outoriteite van die RGN-verslag oor godsiens optree (Van der Westhuizen 1986a), moet jy besef dat Kommunisme komponentsgewys soos op 'n paaiementstelsel infiltreer. Dit kom stuk-stuk en kleef voorlopig vas aan skynbaar assimileerbare samelewingsverbande en omvorm dit tot frontorganisasies (Van der Westhuizen, 1977: 50).

\subsection{Perd van ' $n$ ander kleur}

Marxisme is ' $n$ Trojaanse perd om al die gevare van Kommunisme in Suid-Afrika in te bring. Eintlik is Marxisme nie soos in die geval van Troje ' $n$ houtperd nie, maar ' $n$ houtbeer. Hy doen hom voor as ' $n$ teddiebeer vir akademici soos sosioloë, teoloë en politikoloë. Met sy kloue sou hy dan nie vang nie en met sy kake sou hy dan nie byt nie! Die koue buite die internasionale wêreld waarin die Suid-Afrikaanse offerlammetjie staan, sou verhelp kon word as hy die warm pels van hierdie beer om hom kan hê deurdat die groot beremaag sommer ook meteens in sy imperiale honger 'n bietjie gestil kan word.

Daar moet boonop gewaak word om nie van die Marxistiese houtperd ' $n$ afgodiese goue kalf te maak nie. 


\subsection{PS Dreyer}

Professor Petrus Secundus Dreyer het dertig jaar gelede aan skrywer filosofie doseer. Hy is ' $n$ groot filosoof soos uit die res van hierdie feesbundel blyk. Vir vyf en twintig jaar het skrywer met hom op sendinggebied by die Sendingraad en Dagbestuur saamgewerk, waarvan die afgelope dekade ten opsigte van die opleiding van swart leraars in baie noue verband. Hy is ' $n$ groot teoloog in die sin dat hy vele godsdienstige boeke geskryf het, voortdurend in baie kerklike rade gedien het, en as sendingman fenomenaal baie gedoen het. Ook dit sal uit hierdie feesbundel blyk.*

Maar een ding moet van hom getuig word. Hy het altyd op 'n eenvoudige en gelowige wyse daarop klem gelê dat alles draai om die doel dat 'n mens moet kan bely: Ek glo in Jesus Christus as Verlosser.

Hoe ver staan die twee filosowe Karl Marx en PS Dreyer nie van mekaar nie! Nooit het Dreyer ' $n$ soort filosofie beoefen en 'n soort teologie bedryf waar eintlik gepraat moet word van Karl Christus en Jesus Marx nie. Al sal die tydelike roem van Marx Dreyer miskien ver oortref, is die troos van Paulus op Dreyer van toepassing:

Tree onder hulle op as ligdraers in die wêreld deur die woord van die lewe uit te dra. Dan sal ek op die dag van Christus se koms rede hê om trots te wees, omdat dit sal blyk dat ek my nie verniet ingespan het nie en nie verniet geswoeg het nie (Fil 2: 16).

\footnotetext{
- Vgl die artikel van DJC van Wyk, 'Die Nederduitsch Hervormde Kerk se sendingwerk 1928-1967: Van besinning tot daad,' wat vervolgens in hierdie Nommer van die HTS opgeneem is (Redakteur).
} 


\section{Literatuurverwysings}

BEELD 27 November 1985. Dekmantel.

BESKRYWINGSPUNTE 1963. Federasie van Rapportryerskorpse, Landsberaad 20 en 21 September 1963. Pretoria.

DEGENAAR, JJ 1982. Marxism-Leninism and its implications for South Africa. Societas 14, University of Stellenbosch. Pretoria: Academica.

DIE HERVORMER Februarie 1986. Redaksioneel: Bybel misbruik vir politieke druk, bl 4.

DIEPTEARTIKEL, 1986. Kairos-dokument is rewolusionêr, In Hoc Signo Januarie 1986, bl 10.

DU TOIT, D 1986. Die Kairos-dokument, Die Kerkbode 22 Januarie 1986

ENGELBRECHT, BJ 1964. Die kommunistiese aanslag op die kerk, in Christendom teen kommunisme: Referate gelewer by die Volkskongres oor kommunisme, 24-55. Pretoria: Volkskongres oor kommunisme.

ESTERHUYSE, WP 1984. Karl Marx: Filosoof van die revolusie. Kaapstad: Tafelberg

HARTIN, P 1985. Die Kairos-dokument misbruik die Skrif, Internos Desember 1985, bl 114-117; soos aangehaal en vertaal uit The Southern Cross.

HENNING, K 1986. Die Kairos-dokument: Uitdaging of gevaar? Die Kerkbode 26 Februarie 1986, bl 5, 7 en 8. Vertaling deur Backeberg, HEW uit Idea 23 Januarie 1986.

HEYNS, JA 1986. Dis tyd vir beslissing: Kan Kairos-dokument nie ignoreer of summier uitvoer nie, Beeld 25 Februarie 1986.

INTERNOS Desember 1985. Nuusbrief van die Inligtingsburo van die Nederduitse Gereformeerde Kerk in Suid-Afrika. Kaapstad.

JORDAAN, CL 1986. Resensie van Pike, HR, A history of communism in South Africa, Die Kerkbode 26 Februarie 1986, bl 8.

MAIMELA, SS 1985. Nuclear holocaust: The ultimate in violence, in Vorster, WS (ed), Views on violence, 66-87. Pretoria: University of South Africa.

NURNBERGER, K 1985. ANC: Regering moet weer dink, Rapport 10 November 1985.

SCARBOROUGH, D 1985. Circular letter December 1985 of the Gospel Defence League. Cape Town.

SCHOLTZ, GD 1968. Die proses van gelykmaking. Johannesburg: Voortrekkerpers.

SMITH, T 1986. Kairos-dokument, bevrydingsteologie en invloed van Marxisme, Die Kerkbode 26 Februarie 1986, bl 5 en 7.

THE KAIROS DOCUMENT 1985. Challenge to the church: A theological comment on the political crisis in South Africa. Braamfontein: The kairos theologians.

THE MYTH OF MARXISM 1982. London: Wessex study group.

UCANUUS 1986. Die Kairos-dokument: Die duidelikste infiltrasie van die Christelike kerk tot op hede. Persvrystelling van United Christian Action, 17.02.1986. Pretoria.

VAN DER WESTHUIZEN, HG 1965. Geestelike weerbaarheid, Handhaaf April 1965, bl 5, $10,13,14,15,24,25$ en 27.

VAN DER WESTHUIZEN, HG 1977. Vertrou op God. Kaapstad-Pretoria: HAUM.

VAN DER WESTHUIZEN, HG 1983. Ekumene - Marx of Markus? Pretoria: Kital.

VAN DER WESTHUIZEN, HG 1986a. Sosialistiese Teologie ontmasker. Leer- en Lewenskwessies April 1986.

VAN DER WESTHUIZEN, HG 1986b. Nou en ewig: 'n Preekbundel oor Openbaring. Pretoria: Kital.

VORSTER, JM 1984. Die Neo-Marxistiese politieke teologie in Suid-Afrika: 'n Gereformeerd-apologetiese studie. D Th-proefskrif, Potchefstroomse Universiteit vir Christelike Hoër Onderwys.

VORSTER, JM s a. Die kruis of die vuis? Kerk en revolusie in Suid-Afrika. Drukker en uitgewer nie vermeld nie. 